\title{
Obituary
}

\section{Obituary: Prof. Pietro Luigi Indovina}

\section{Dear Physica Medica Readers,}

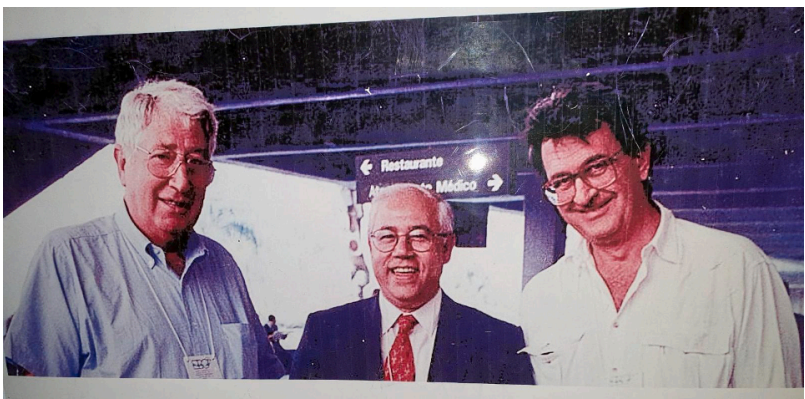

World Congress on Medical Physics and Biomedical Engineering. Rio de Janeiro, Brazil, 21-26 August 1994 - From left to right A. Stefanini, P. L. Indovina, G. Arcovito.

We have been just informed that Prof. Piero Luigi Indovina passed away in Rome, Italy.

On 20 March 2021 the medical physics community lost a very special member - Prof. Pietro Luigi Indovina, "Piero" for his friends.

Piero was a charismatic figure who dedicated his life to medical physics providing a relevant contribution to the development of this discipline in Italy. From 1987 to 1992 he was President of AIFB - Italian Association of Biomedical Physics and, in 1999, co-founder of AIFM the Italian Association of Medical Physics.

Piero's scientific activity has always been driven by curiosity and the need to give concrete answers to the problems that emerged, from time to time, in the field of life sciences.

Piero starts his scientific activity in 1966 at ISS (Istituto Superiore di Sanità, an Institute of the Italian Minister of Health) reaching, within twenty years of intense activity, the position of Director of the Department of Biomedical Physics. In this first part of his scientific activity Piero investigated structure and function of biological systems of increasing complexity ranging from molecules to cells and tissues with innovative approaches like Electron Spin or Paramagnetic Resonance.

Piero, in 1987, gained the position of Full Professor of Applied Physics at the University of Naples "Federico II". From 2000 to 2006, he also was Director of the Post-Graduate School in Medical Physics titled "Scuola di Specializzazione in Fisica Sanitaria" at Federico II University. In this phase of his scientific production, he devoted himself more intensely to medical physics, contributing to the development of $3 \mathrm{D}$ imaging techniques using ionizing radiation, non-ionizing radiation such as nuclear magnetic resonance and even unconventional radiation such as synchrotron radiation for mammography. Later, from 2000 to his retirement in 2010, Piero dedicated himself to the optical characterization of complex multicellular biological systems representing a step forward in the simulation of the in vivo behavior of tumors.

Along with his academic commitments Piero also developed a rich professional activity in the area of safety with professional assignments as in Medical Physics Expert both in public and private structures of national relevance. From 1980 to 1988 he was Member of the National Commission for the attribution of the qualification of "Radiation Protection Expert".

Besides his indisputable competence and professionalism combined with his experience, Piero was appreciated for his particular ability in stimulating and promoting students and collaborators.

He was a unique professional, pioneer and educator with a remarkable predisposition to training and dissemination that will be missed by our community.

Rome, 20 March 2021

Giuseppe Arcovito Università Cattolica Sacro Cuore, Rome, Italy

Marco De Spirito Università Cattolica Sacro Cuore, Rome, Italy

Roberto Pani Sapienza Università di Roma, Rome, Italy 